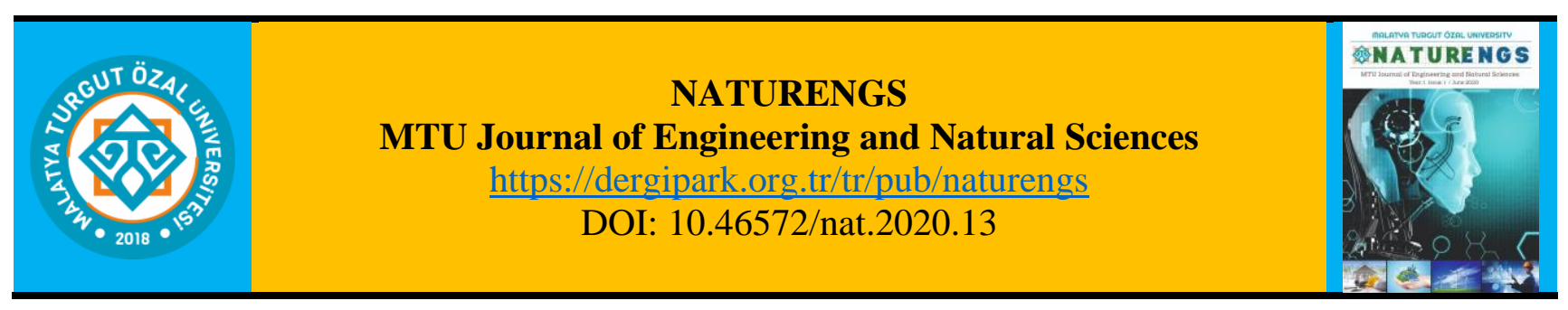

\title{
Influence of a Clay Subgrade Stabilized with Blast Furnace Slag on Flexible Road Pavement Thickness and Cost
}

\author{
Tacettin GEÇKİL ${ }^{1}$, Mehmet Mahmut TANYILDIZI ${ }^{2 *}$, Ceren Beyza INCE ${ }^{3}$, Ekrem Serdar YILDIRAN ${ }^{4}$ \\ ${ }^{1,3}$ Department of Civil Engineering, İnönü University, Malatya, Turkey. \\ ${ }^{2}$ Second Army Command, Malatya, Turkey. \\ ${ }^{4}$ Togi Metal Construction, Malatya, Turkey.
}

(Received: 03.08.2020; Accepted: 06.10.2020)

\begin{abstract}
It has become a necessity in Highway Engineering, due to today's heavy vehicle traffic loads, that subgrade with poor bearing capacity on which the road will rest be improved with various methods and additives. In this study, it has been aimed to improve clay soil with poor bearing strength with the contribution of waste blast furnace slag (BFS) and to investigate its effect on the thickness and cost of flexible road pavement. This study aims to improve clay soil with poor bearing strength with the contribution of waste BFS. Moreover, it tries to investigate the effects of BFS on the thickness and cost of flexible road pavement. For this purpose, in the study, stabilized mixture samples were prepared by adding 5, 10, 15, 20\% by weight of BFS to the clay soil. After these prepared samples have been mixed homogeneously, standard proctor, unconfined compression and California Bearing Ratio (CBR) tests were applied to the samples. As a result of experimental studies, it was observed that the increase in BFS resulted in a decrease in the maximum dry density of the samples and an increase in the optimum moisture content. Also, the highest unconfined compression strength was obtained from $20 \%$ of BFS added samples. CBR values of the samples tested at this rate increased by 8.71 times compared to pure clay soil. Using these experimental data, the flexible road pavement layer thicknesses to be constructed with the AASHTO 1993 method on the BFS added ground were calculated, and pavement cost analyzes were made considering current prices. As a result of the calculations, the design calculation was made according to the layer thicknesses determined for both soils. it was determined that adding $20 \%$ BFS to the soil decreased the road pavement layer thickness by $29.41 \%$ compared to the pure clay soil. The cost calculation results show that compared to the pure clay soil, there is about a $5.65 \%$ decrease in the pavement cost for clayey soils with $20 \%$ BFS. According to these results, when the subgrade of a $1000 \mathrm{~m}$ in length and $20 \mathrm{~m}$ in width road is improved with $20 \% \mathrm{BFS}, 8.400,00 \mathrm{TL}$ saving will be provided in the cost of flexible pavement.
\end{abstract}

Keywords: Clay soil, Blast furnace slag, Stabilization, Flexible pavement, AASHTO method.

\section{INTRODUCTION}

Nowadays, the problems encountered in the disposal of the wastes arising as a result of developing industry and technology, increasing population, and growing cities have reached day by day unignorable levels. For this reason, the disposal of industrial and industrial wastes has become very important. For this purpose, the use of various waste materials has become quite common in different civil engineering applications such as ground stabilization and filling formation $[1,2]$. Ground stabilization is generally the process to improve the strength of the soils by adding various additives to the soils with poor bearing capacity.

*Corresponding Author: mmtanyildizi@hotmail.com

ORCID number of authors: ${ }^{1}$ 0000-0001-8070-6836, ${ }^{2}$ 0000-0001-5992-2665, ${ }^{3}$ 0000-0002-6385-0964,

${ }^{4}$ 0000-0002-8678-5544 
Ground stabilization is generally the process to improve the strength of the grounds by adding various additives to the subgrade with poor bearing capacity. For this purpose, lime, blast furnace slag, fly ash, cement, etc. are used to remove the negative properties of the ground. It is tried to increase the strength of the grounds by adding chemical additives [3]. It has been observed that the properties of the soils can be improved in their properties such as volumetric stability, strength, permeability, compressibility, durability by using these additives.

Furthermore, the cost efficiency and easy availability of these additives have made them preferable for their use in the improvement or stabilization of the ground [4-6].

Clay soils with poor bearing capacity, high shrinkage, swelling, permeability and liquefaction potential, low shear strength, which are undesirable to be found in road construction work, are generally called weak grounds. Therefore, in road construction works encountered with this type of ground, soils with high bearing capacity and no swelling potential (better geotechnical properties) are obtained by using additives [7].

In this study, the effect of waste BFS on the strength of a clay road subgrade with poor bearing capacity was investigated and, this situation was evaluated in terms of road flexible road pavement cost in the light of the findings obtained as a result of experimental research.

Emerging as a byproduct during iron and steel production, BFS is used in various engineering applications such as road pavements and filling material in road engineering. The structure of BFS consists of 95\% elements such as silica, calcium, aluminum, magnesium and oxygen [710]. It is thought that using BFS, which is obtained as a byproduct with these features, to increase the strength of weak soils will be beneficial both in terms of bearing capacity of the soil, waste disposal and economic gain [10].

In many countries, positive results have been obtained in soil improvement studies carried out using BFS. Studies have shown that BFS is not affected by groundwater and is suitable for use in the land and that BFS can be used as an additive in road stabilization [11, 12].

Sivrikaya et al. [13] have investigated the usability of BFS to increase the strength of clay soils. For this purpose, 5\%, 10, 20, 30 and 50\% of BFS were added to two different clay soils, and the properties of the samples were examined. It was determined for both pure clay soils that as the BFS ratio increased, the bulk density also increased. Similarly, while the plastic limit (PL) values of clay soils increased, liquid limit (LL) values decreased. When these results were evaluated, it was found that the plasticity indexes (PI) of the clays decreased in the range of 92$180 \%$. The decrease in PI values with BFS contribution has resulted in reduced sensitivity of clay soils to water.

Bilgen et al. [14] have investigated the usability of BFS and lime in improving the strength of clayey soils. Within the scope of the study, mixed samples have been prepared between $0 \%$ and $7.5 \%$ for BFS and $0 \%$ and $5 \%$ for lime, and the properties of these samples have been determined. According to the results of the experiment, it has been determined that BFS has no effect on plasticity alone, but plasticity has decreased from 28 to 9 in 5\% lime and 3.33\% BFS mixture. BFS did not cause a significant change in the optimum moisture content when used alone or in combination with lime. When BFS is used alone, it increases the unconfined compressive strength by approximately two times, and when the mixture of 5\% lime and $3.33 \%$ BFS is used together, the unconfined compressive strength increases 11 times. 
Cokca et al. [15] investigated the effects of the BFS and BFS-cement mixture on the strength of the soils with swelling properties. Within the scope of the study, a 5\% to 25\% BFS and BFScement mixture has been added to the soil samples. The effects of these additives on grain size distribution, Atterberg limits, rate of swelling have been investigated. As a result of the experimental studies, it was determined that as the amount of additive increased, the plasticity index (PI) and swelling percentage of the soils decreased, while its specific gravity increased. As a result of the study, it was concluded that a 15\% BFS - 5\% cement mixture is the most optimum option considering both environmental effects and swelling percentage.

Bilici et al. [16] The ground was mixed in different proportions with the waste material, BFS and fly ash (FA). In the series with additives, lime is kept constant at $3 \%$ in order to ensure the pozzolanic reaction, in the first stage 3\%,6\%, 9\%, 12\%, 15\% FA and in the second stage 3\%, $6 \%, 9 \%, 12 \%$ BFS additive series Uncured (early period), 7 days and 28 days unconfined compression tests were applied to the prepared samples. In this context, by reducing the soil sample in work with additives, lime, FA and BFS were added as much as it was reduced, thus keeping the dry mass of the total mixture constant. It has been determined that the highest strength occurs at 3\% lime $+12 \%$ FA and 3\% lime $+9 \%$ BFS additives.

Geçkil et al. [17] The effect of adding lime to clay soil on strength was investigated. For the study, lime, which is used as an additive, was added to the clay soil in different percentages by weight. In the prepared mixtures, lime was added in $2.5 \%, 5 \%, 7.5 \%, 10 \%, 15 \%$ and $20 \%$ of the weight of clay. The samples prepared in different proportions were homogeneously mixed, and then compaction, unconfined compression and CBR tests were performed. As a result of experimental studies, as the lime content in the mixture increased, the plasticity index and maximum dry density decreased while the optimum moisture content increased. In addition, the highest unconfined compressive strength value of the samples cured for 7 and 28 days was obtained at the rate of $5 \%$ lime. For this additive ratio, the CBR values of the samples cured at the same time were 1.37 and 2.08 times higher than the additive-pure clay soil, respectively.

In this study, unlike other studies conducted in the literature [16, 17], the effect of a clayey road subgrade with improved bearing capacity with BFS on flexible road pavement layer thicknesses and costs have been investigated. For this purpose, compression, unconfined compression, CBR tests were carried out on soil samples with increased strength, and with the help of the AASHTO 1993 design method, flexible pavement layer thicknesses have been determined on the soil with pure clay and BFS, and their current costs have been calculated. In a study in the literature [18] a clay soil stabilized with BFS, the samples prepared by adding 5, 10, 15, 20\% BFS to the clay soil by weight, Standard Proctor, unconfined compression and CBR tests. As a result of the experiment, it was determined that the highest strength was obtained from mixtures containing $20 \%$ BFS. In the design calculations made according to the layer thicknesses determined for both ground with the AASHTO 1993 method, it was determined that adding 20\% BFS to the ground reduced the thickness of the road pavement layer by $26.67 \%$ compared to the pure clay soil. In this study, it was determined that the highest strength was obtained with $20 \%$ BFS as a result of 7 days of curing under the same test conditions, but the thickness of the road pavement layer was decreased by $29.41 \%$.

\section{MATERIAL AND EXPERIMENTAL STUDIES}

Within the scope of experimental studies, clay material was used as a road subgrade provided from the Malatya Kiltepe region. The engineering properties of the clay material are determined according to the TS 1900-1 standard and are shown in Table 1. 
Table 1. Physical properties of clay soil

\begin{tabular}{|l|c|c|}
\hline \multicolumn{1}{|c|}{ Parameter } & Unit & Value \\
\hline Density of particles $\left(\gamma_{\mathrm{s}}\right)$ & $\mathrm{g} / \mathrm{cm}^{3}$ & 2.680 \\
\hline Maximum dry density $\left(\mathrm{g}_{\mathrm{kmax}}\right)$ & $\mathrm{g} / \mathrm{cm}^{3}$ & 1.450 \\
\hline Optimum moisture content $\left(\mathrm{w}_{\mathrm{opt}}\right)$ & $\%$ & 27 \\
\hline Liquid limit $(\mathrm{LL})$ & $\%$ & 61 \\
\hline Plastic limit $(\mathrm{PL})$ & $\%$ & 29 \\
\hline Plasticity index (PI) & - & 32 \\
\hline Unified soil classification system (USCS) & - & $\mathrm{CH}$ \\
\hline AASHTO classification system & & A-7-6 \\
\hline
\end{tabular}

By the Highways Technical Specifications (HTS) data, stabilization-improvement is envisaged for the soils classified as A5, A6, A7, A-2-6, A-2-7 in AASHTO classification system [19]. While the class of soil provided in the study is determined as high plasticity clay $(\mathrm{CH})$ according to the unified soil classification system (USCS) data, it is determined as A-7-6 (poorest soil) according to AASHTO classification system data. Besides, since clay soil is PI $32 \geq 10$, the strength of clay soil with a poor bearing capacity was increased by stabilization following HTS.

BFS having a specific weight of $2.750 \mathrm{~g} / \mathrm{cm}^{3}$ and used to improve the strength of the clay soil was provided from Karçimsa cement factory in Karabük province, and its chemical properties are shown in Table 2.

Table 2. Chemical properties of blast furnace slag (BFS)

\begin{tabular}{|c|c|c|c|c|c|c|c|c|c|c|c|c|}
\hline $\begin{array}{c}\text { Chemical } \\
\text { Component }\end{array}$ & $\mathrm{SiO}_{2}$ & $\mathrm{Al}_{2} \mathrm{O}_{3}$ & $\mathrm{Fe}_{2} \mathrm{O}_{3}$ & $\mathrm{CaO}$ & $\mathrm{MgO}$ & $\mathrm{SO}_{3}$ & $\mathrm{~S}$ & $\mathrm{Na}_{2} \mathrm{O}$ & $\mathrm{K}_{2} \mathrm{O}$ & $\mathrm{TiO}_{2}$ & $\mathrm{Mn}_{2} \mathrm{O}_{3}$ & $\mathrm{Cl}$ \\
\hline $\begin{array}{c}\text { Content by } \\
\text { Weight (\%) }\end{array}$ & 32.47 & 9.94 & 1.25 & 32.45 & 9.31 & 0.82 & 0.33 & 0.31 & 0.85 & 1.16 & 3.51 & 0.015 \\
\hline
\end{tabular}

Within the scope of the study, before the clay-BFS mixture samples have been prepared, both materials have been dried in an oven of $105 \pm 5^{\circ} \mathrm{C}$ for 24 hours. Then, taking into consideration the previous studies [12-14] in the literature, clay stabilized mixtures have been prepared by adding 5, 10, 15 and $20 \%$ BFS by weight.

In the whole study, pure clay and stabilized mixtures have been named clay, $5 \%$ BFS, $10 \%$ BFS, $15 \%$ BFS and $20 \%$ BFS respectively.

In the study, three samples of pure clay and stabilized mixture samples were prepared, and the Standard Proctor experiment has been carried out on the samples following TS 1900-1. While stabilized samples have been tested for optimum moisture content ratio determination, Sodium 
Hydroxide $(\mathrm{NaOH})$ solution instead of water has been added [20] to increase the pozzolanic reactivity of the BFS and provide good adherence with the soil.

As a result of the compression studies, the dry density-moisture content graphs obtained as a result of the standard proctor experiments of the samples are shown in Figure 1.

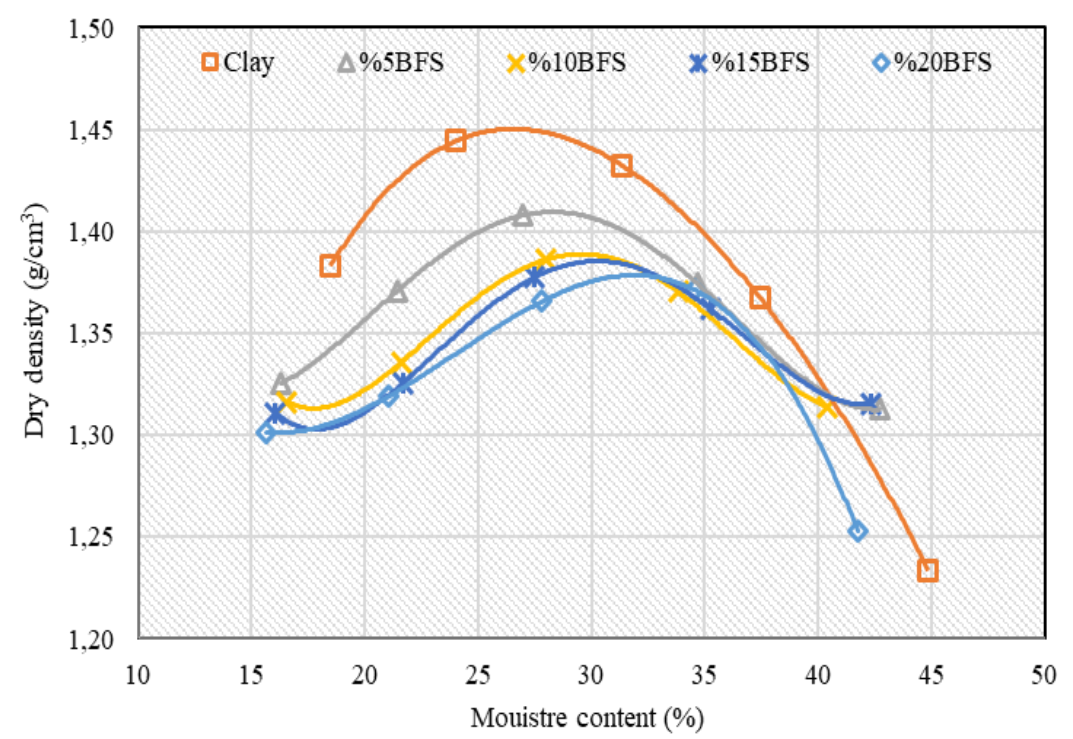

Figure 1. Dry density $\left(\mathrm{g}_{\mathrm{k}}\right)$ - moisture content $(\%)$ graphic of samples

When Figure 1 is taken into consideration, it is observed that there is a decrease in the maximum dry densities of the samples and an increase in the optimum moisture content in proportion to the rise in the amount of BFS. It is thought that the increase in moisture content and the decrease in dry density are due to the high water absorption potential of BFS and its fine grain [20].

The unconfined compression test is an experiment that is generally used to determine the slip resistance in water-saturated normal consolidated clayey soils, and the soil resistance can be calculated from the Mohr circle obtained as a result of the test. In the experiment, cylindrical cohesion soil samples, preferably $38 \mathrm{~mm}$ in diameter and $76 \mathrm{~mm}$ in length, are used. This experiment is carried out in two ways: stress-controlled and deformation-controlled, but the one with unit length shortening control is commonly preferred. Since the experiment may cause changes in the moisture content of the sample during the experiment, it should be completed within 5-10 minutes, and the unit height shortening should be $0.5 / \mathrm{min}-2 \% / \mathrm{min}$. The experiment can be completed when the load carried by the sample starts to decrease or after the length shortening reaches $20 \%$. In this experiment, the greatest value of axial stress gives the unconfined compressive strength $\left(\mathrm{q}_{\mathrm{u}}\right)$. The undrained shear strength is obtained by $\tau=\mathrm{c}_{\mathrm{u}}=\mathrm{q}_{\mathrm{u}}$ / 2 relation [21].

Within the scope of the experimental studies, mixture samples were prepared to subject them to unconfined compression and CBR tests, taking into account the optimum moisture content found as a result of the Standard Proctor experiment. First, all prepared samples were subjected to a 7-day curing period and were subjected to an unconfined compression experiment at the end of this period. Stress-Strain graphics obtained by mixed pure samples as a result of the 7day curing period are given in Figure 2. 


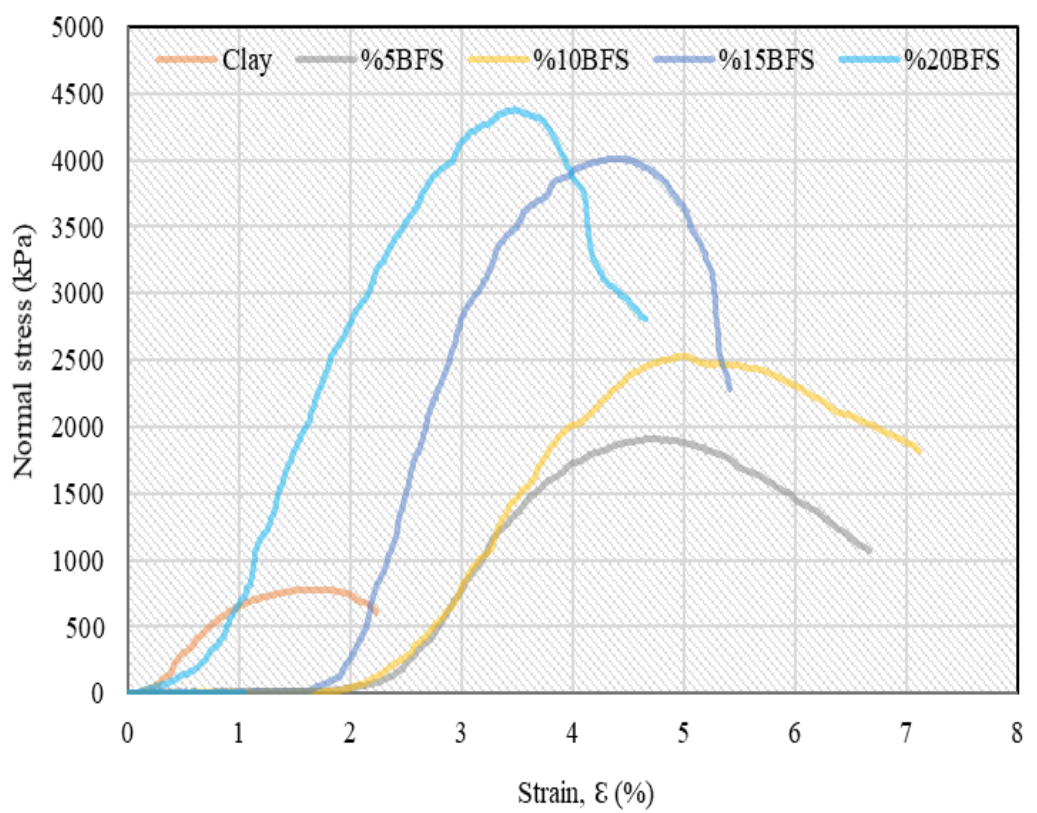

Figure 2. Unconfined compression test results of pure and BFS additive samples

As seen in Figure 2, it was determined that the maximum unconfined compression resistance among the prepared mixtures belongs to clay samples with $20 \%$ BFS additive. At the end of the 7-day curing period, a significant increase in unconfined compression resistance of the stabilized clay has been observed with a $20 \%$ BFS additive. This situation is considered to be caused by the BFS being a pozzolanic material and the late strength of the pozzolanic materials. However, considering the previous studies using BFS, it is seen that the rates giving maximum strength differ from each other [12-14]. As a result of the researches, it is considered that this difference is probably due to the structural differences of the clays and BFS used and the type and amount of the solutions used to increase the pozzolanic reaction, as stated in a similar study by Arulrajah [20]. Also, Bilici et al. [16] prepared mixture samples using different amounts of waste BFS and FA in their study. Samples of 3\%, 6\%, 9\%, 12\%, 15\% FA in the first stage and $3 \%, 6 \%, 9 \%, 12 \%$ BFS samples in the second stage were tested for 7 days 28 days unconfined compression test. They found that the highest strength occurred in samples with $3 \%$ lime $+12 \%$ FA and 3\% lime $+9 \%$ BFS. They evaluated the reason for this situation because BFS has higher pozzolanic property.

However, considering the previous studies using BFS, it is seen that the rates giving maximum strength may differ from each other [12-14]. As a result of the examinations made, it has been observed that this difference may result from structural differences of the clays and BFS used and the type and amount of the solutions used to increase the pozzolanic reaction.

Pure and stabilized mixture samples have been subjected to CBR test after the most effective additive rate was obtained as $20 \%$ as a result of the unconfined compression tests. For this purpose, mixture samples containing pure clay and 20\% BFS have been prepared and, these samples were subjected to a curing period of 7 days. In the study, two samples were prepared for each experiment in parallel with the studies in the literature $[13,14]$. CBR test results of pure clay and 20\% BFS added mixture samples are shown in Table 3. 
Table 3. CBR values of pure clay and $20 \%$ BFS added mixture samples

\begin{tabular}{|c|c|c|c|}
\hline Sample & $\begin{array}{c}\text { Curing } \\
\text { Period }\end{array}$ & CBR $(\mathbf{2 . 5} \mathbf{~ m m}),(\boldsymbol{\%})$ & CBR (5 mm), (\%) \\
\hline \multirow{2}{*}{ Pure clay } & \multirow{2}{*}{ 7 days } & 31.2 & 25.6 \\
\cline { 3 - 4 } Pure clay+\%20 BFS & & 179.7 & 222.9 \\
\hline
\end{tabular}

As shown in Table 3, CBR values of 2.5 and $5 \mathrm{~mm}$ displacements of the Pure Clay subjected to a 7-day curing period were determined as $31.2 \%$ and $25.6 \%$, respectively, and CBR values of $20 \%$ BFS-added clay soils corresponding to the same displacements were determined as $179.7 \%$ and $222.9 \%$ respectively as a result of experiments. Accordingly, CBR values of samples containing 20\% BFS compared to pure clay soil increased by 5.76 and 8.71 times, respectively. These results show that BFS has a very positive effect on the clay soil's resistance to swelling deformations. In a study conducted in the literature [22] The change in swelling pressure and swelling percentages was investigated by adding slaked lime in different proportions $(1 \%, 3 \%, 5 \%, 7 \%, 9 \%)$ by weight to "CH" clays, which may pose a risk for light structures and have high swelling potential. For all experimental samples, it was determined that as the lime additive ratio by weight increased, the CBR values increased and when it was $5 \%$, the swelling percentage and swelling pressure decreased on average $91 \%$, respectively.

\section{RESULTS AND DISCUSSION}

\subsection{Analytical Investigation of Bearing Capacity in Flexible Pavement by AASHTO Method}

Highway pavements are generally designed in two ways: flexible and rigid road pavements. Flexible road pavements where asphalt cement is used as binder material by and large consists of asphalt concrete coating, foundation and subbase layers. Pavements consisting of a coating layer constructed using portland cement are called rigid road pavements and these structures are conventionally composed of foundation and concrete slab coating [25]. A typical flexible road pavement section is given in Figure 3 below.



Subgrade (Existing Soil)

Figure 3. A typical flexible pavement section view [23]

In highway flexible pavement design, the aim is to determine the thickness of the pavement layers that can safely carry the traffic that will recur during the design life of the projected road 
and to determine the properties of the materials that will form the pavement layers. In this context, the empirical equation given in Equation 1 is used in the calculation of AASHTO 1993 pavement layer thicknesses. Using this equation, the Number of Pavement ( $\mathrm{SN}$ ) value is calculated for flexible pavement design [24].

$$
\begin{aligned}
& \log T_{8,2}=Z_{R} \times S_{0}+9,36 \times \log _{10}(\mathrm{SN}+1)-0,20+\frac{\log (\Delta \mathrm{PSI} /(4,2-1,5))}{0,40+[1094 /(\mathrm{SN}+1)} \\
& +2,32 \times \log _{10}\left(\mathrm{M}_{\mathrm{R}}\right)-8,07
\end{aligned}
$$

In this place;

T8.2: The number of standard axles (8.2 tons) that will repeat during service life

$\mathrm{M}_{\mathrm{R}}$ : Subgrade resilient modulus, psi $\left(6.8950 \times 10^{3} \mathrm{~Pa}\right)$

$S_{0}$ : Total standard deviation

$\mathrm{Z}_{\mathrm{R}}$ : Standard normal deviate

$\mathrm{SN}$ : Structural number (inches)

$\mathrm{P}_{0}$ : İnitial design serviceability index

$\mathrm{P}_{\mathrm{t}}$ : Design terminal serviceability index

$\triangle$ PSI: Difference between the initial design serviceability index, $\mathrm{P}_{\mathrm{o}}$, and the design terminal serviceability index, $\mathrm{P}_{\mathrm{t}}\left(\mathrm{P}_{0}-\mathrm{P}_{\mathrm{t}}\right)$

After the SN value is calculated with Equation 1, the required, flexible pavement layer thicknesses are calculated with Equation 2, considering the layer coefficients given in Table 4 [23].

$\mathrm{SN}=\mathrm{a}_{1} \times \mathrm{D}_{1}+\mathrm{a}_{2} \times \mathrm{D}_{2} \times \mathrm{M}_{2}+\mathrm{a}_{3} \times \mathrm{D}_{3} \times \mathrm{M}_{3} \ldots \ldots \ldots \ldots . \mathrm{a}_{\mathrm{i}} \times \mathrm{D}_{\mathrm{i}}$

In this equation; a1, a2, a3 respectively are the structural layer coefficients of the coating, base and subbase layers, $D_{1}, D_{2}, D_{3}$ are layer thicknesses of coating, base, subbase, $M_{2}, M_{3}$ are the drainage coefficients of base and subbase layers.

In this study, the drainage coefficients are considered as 1.00 in the calculation of flexible road pavement layer thicknesses.

Table 4. AASHTO layer coefficients [24]

\begin{tabular}{|l|c|c|c|}
\hline \multicolumn{1}{|c|}{ Layer type } & Marshall Stability (kg) & CBR (\%) & $\begin{array}{c}\text { Relative Strength } \\
\text { Coefficient (a) }\end{array}$ \\
\hline Surface course & $\geq 900$ & - & 0.42 \\
\hline Wearing course & $\geq 750$ & - & 0.40 \\
\hline Binder course & $\geq 600$ & - & 0.36 \\
\hline Bituminous base course & - & $\geq 100$ & 0.14 \\
\hline Base course & - & $\geq 120$ & 0.15 \\
\hline Granular base & - & $\geq 30$ & 0.11 \\
\hline Plant mix base & - & $\geq 50$ & 0.13 \\
\hline Subbase & - & \\
\hline Sand-gravel subbase & \multicolumn{5}{|l|}{} \\
\hline Crushed-stone subbase &
\end{tabular}


After determining the flexible pavement layer thicknesses, $\mathrm{SN}^{*}$ values given in Figure 4 were calculated, and the control of the layer thicknesses has been made.
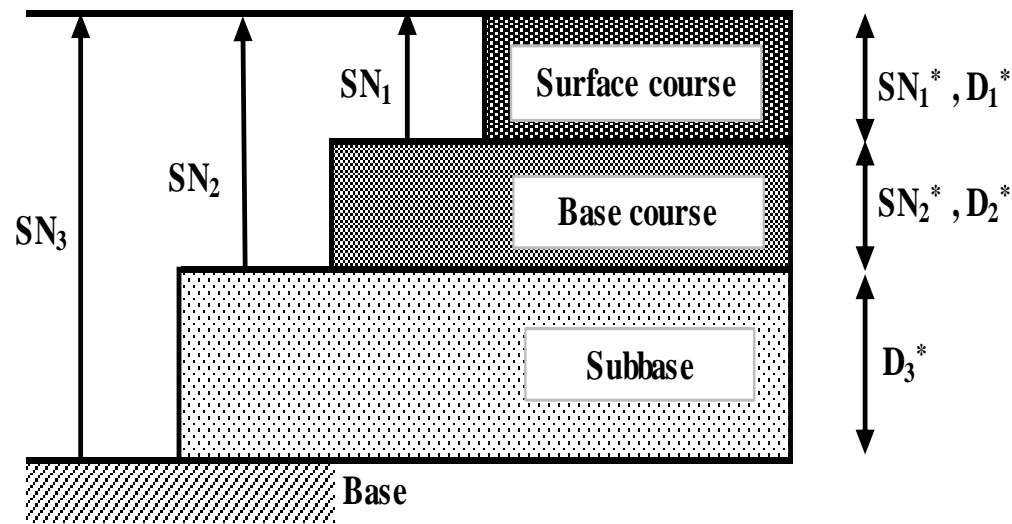

Figure 4. Pavement numbers in flexible pavement

$\mathrm{SN}_{1}$ : $\mathrm{SN}$ required on the base layer

$\mathrm{SN}_{2}$ : $\mathrm{SN}$ required on subbase layer

$\mathrm{SN}_{3}$ : Required $\mathrm{SN}$ on base soil

*: It shows the current values according to the material used.

In the study, to determine the effects of BFS on the flexible road pavement, flexible pavement design was made with the AASHTO 1993 method, taking into account the optimum strength and 7-day curing time.

\subsection{Analytical Investigation of Base Soil Bearing Capacity of Pure and $20 \%$ BFS Additive Clay Soil in Flexible Pavement with AASHTO Method}

In the 20-year project life, roads with an equivalent standard axle load repetition number of more than $60-75 \times 10^{6}$ were recommended to be made rigid. It is foreseen that the roads with an equivalent standard axle load repetition number lower than this value will be made flexible road pavement [25].

For flexible pavement design, CBR values of $20 \%$ BFS added clay soil at the end of the 7-day curing period have been taken as a basis. Calculations were made using the CBR values of $\% 31.2$ ve $\% 222.9$ which have been obtained from pure and $20 \%$ BFS added clay soils, respectively.

For this, first of all, it is necessary to calculate the modulus of elasticity $\left(\mathrm{M}_{\mathrm{R}}\right)$ of the soil of the road whose pavement will be designed with the AASHTO method.

$M_{R}=1500 \times C B R$ connection is available between the $M_{R}$ and $C B R$ values of the soil, and if the CBR value of the soil is known, the $M_{R}$ value can be approximately calculated [26].

Accordingly, $\mathrm{M}_{\mathrm{R}}$ values for pure and $20 \%$ BFS added clay soil were determined as 46.800 psi (322674641,32 Pa) for clay soil and $334.350 \mathrm{psi}(2305262101 \mathrm{~Pa})$ for $20 \%$ BFS added clay soil, respectively. Using the data in Table 5, the $\mathrm{SN}_{3}(\mathrm{SN})$ required on the base for pure and $20 \%$ BFS added clay soils were calculated with the help of Equation 1 as 6.16 inches (15.65 $\mathrm{cm})$ and 3.11 inches $(7.90 \mathrm{~cm})$, respectively. 
Table 5. Parameters used in flexible pavement design [25]

\begin{tabular}{|l|c|}
\hline \multicolumn{1}{|c|}{ Parameter } & Selected Values \\
\hline Equivalent standard axle load repetition number, $\mathrm{T}_{8,2}$ & 50.000 .000 \\
\hline Standard normal deviate, $\mathrm{Z}_{\mathrm{R}}($ State road $\mathrm{R}=\% 85)$ & -1.037 \\
\hline The first serviceability of the road, $\mathrm{P}_{0}$ & 4.20 \\
\hline The last serviceability of the road, $\mathrm{P}_{\mathrm{t}}($ For motorways, state roads 2.5$)$ & 2.50 \\
\hline Service capability index, $\Delta \mathrm{PSI}$ & 1.70 \\
\hline Total standard deviation, $\mathrm{S}_{0}$ & 0.45 \\
\hline
\end{tabular}

\subsection{Determination of Flexible Pavement Layer Thicknesses for Pure and 20\% BFS Additive Soil and Control of These Thicknesses}

With Equation 1, the $\mathrm{SN}_{3}$ values for pure clay ground are calculated as 6.16 inches $(15.65 \mathrm{~cm})$ and 3.11 inches $(7.90 \mathrm{~cm})$ for the $20 \%$ BFS-added soil. The selected flexible road pavement layer thicknesses are given in Table 6, and layer thicknesses selected for $20 \%$ BFS added soil are shown in Table 7.

Table 6. Recommended layer thicknesses for pure clay soil

\begin{tabular}{|c|c|c|}
\hline Layer Name & $\begin{array}{c}\text { Recommended } \\
\text { Thickness }\left(\mathbf{D}_{\mathbf{i}}\right),(\mathbf{c m})\end{array}$ & Layer Coefficient $\left(\mathbf{a}_{\mathbf{i}}\right)$ \\
\hline Wearing Course & 5 & 0.42 \\
\hline Binder Course & 10 & 0.40 \\
\hline Bituminous Base Course & 11 & 0.36 \\
\hline Plant Mix Base & 25 & 0.15 \\
\hline Crushed-Stone Subbase & 15 & 0.13 \\
\hline
\end{tabular}

Table 7. Recommended layer thickness for soil with $20 \%$ BFS additive

\begin{tabular}{|c|c|c|}
\hline Layer Name & $\begin{array}{c}\text { Recommended } \\
\text { Thickness }\left(\mathbf{D}_{\mathbf{i}}\right),(\mathbf{c m})\end{array}$ & Layer Coefficient $\left(\mathbf{a}_{\mathbf{i}}\right)$ \\
\hline Wearing Course & 5 & 0.42 \\
\hline Binder Course & 10 & 0.40 \\
\hline Bituminous Base Course & 11 & 0.36 \\
\hline Plant Mix Base & 25 & 0.15 \\
\hline Crushed-Stone Subbase & - & - \\
\hline
\end{tabular}

Total pavement layer thicknesses determined for pure and $20 \%$ BFS added clay soil was determined as $66 \mathrm{~cm}$ and $51 \mathrm{~cm}$, respectively. For clayey soils containing 20\% BFS, it was determined that the layer thickness decreased by $29.41 \%$ compared to the pure soil. 
To control the selected layer thicknesses, the plant mix base is selected from Table 4 as CBR $=$ 120 , and the crushed stone subbase is $C B R=50$ and the plant mix base is calculated as $M_{R}=$ $180.000 \mathrm{psi}$ and the crushed stone subbase is calculated as $\mathrm{M}_{\mathrm{R}}=75.000 \mathrm{psi}$. After calculating the $\mathrm{M}_{\mathrm{R}}$ value, the required $\mathrm{SN}$ values on these layers were calculated as $\mathrm{SN}_{1}=3.93$ inches $(9.98$ $\mathrm{cm})$ for the plant mix base with the help of Equation 1 and $\mathrm{SN}_{2}=5.32$ inches $(13.51 \mathrm{~cm})$ for the crushed stone subbase.

Flexible road pavement layer thickness control calculated for pure clay soil is given in Table 8, and $20 \%$ BFS is added to soil in Table 9.

In the calculations in Table 8 and Table 9, the relative strength coefficients of wearing, binder, bituminous base course, base and subbase layers, $\mathrm{D}_{1}, \mathrm{D}_{2}, \mathrm{D}_{3}, \mathrm{D}_{4}, \mathrm{D}_{5}$ show wearing, binder, bituminous base course, base and subbase layer thicknesses.

Table 8. Control of flexible pavement layer thicknesses for pure clay soil

\begin{tabular}{|c|c|c|c|c|c|c|c|c|c|c|c|}
\hline $\begin{array}{c}D_{1} \\
(\mathbf{c m})\end{array}$ & a1 & $\begin{array}{c}\mathrm{D}_{2} \\
(\mathbf{c m})\end{array}$ & $\mathbf{a}_{2}$ & $\begin{array}{c}\mathrm{D}_{3} \\
(\mathbf{c m})\end{array}$ & $\mathbf{a} 3$ & $\begin{array}{c}\mathrm{D}_{4} \\
(\mathrm{~cm})\end{array}$ & $\mathbf{A}_{4}$ & $\begin{array}{c}\mathrm{D}_{5} \\
(\mathrm{~cm})\end{array}$ & A5 & $\begin{aligned} & \mathbf{S N}^{*} \\
= & \mathbf{a}_{\mathbf{i}} \times \mathbf{D}_{\mathbf{i}}\end{aligned}$ & Definitions \\
\hline 5 & 0.42 & 10 & 0.40 & 11 & 0.36 & - & - & - & - & $\begin{array}{c}\mathrm{SN}_{1}{ }^{*} \\
=10.06\end{array}$ & $\begin{array}{l}\text { For plentmix } \\
\text { crushed stone } \\
\text { base } \mathrm{SN}_{1}{ }^{*}>\mathrm{SN}_{1} \\
(10.06>9.98) \\
\text { appropriate. }\end{array}$ \\
\hline \multicolumn{12}{|c|}{$\begin{array}{c}\mathrm{D}_{4}{ }^{*}=\left(\mathrm{SN}_{2}-\mathrm{SN}_{1}{ }^{*}\right) / \mathrm{a}_{4}=(13.51-10.06) / 0.15=23 \mathrm{~cm}, \text { Selected } \mathrm{D}_{4}=25 \mathrm{~cm} \\
\mathrm{SN}_{2}{ }^{*}=25 \times 0.15=3.75 \\
\mathrm{SN}_{1}{ }^{*}+\mathrm{SN}_{2}{ }^{*}=10.06+3.75=13.81 \geq 13.51\left(\mathrm{SN}_{2}\right)\end{array}$} \\
\hline \multicolumn{12}{|c|}{$\begin{array}{c}\text { For pure clay soil; } \mathrm{D}_{5}{ }^{*} \geq\left(\mathrm{SN}_{3}-(\mathrm{SN} 1 *+\mathrm{SN} 2 *)\right) / \mathrm{a}_{5} \\
\mathrm{D}_{5} * \geq(15.65-(10.06+3.75)) / 0.13 \\
\mathrm{D}_{5}{ }^{*} \geq 14.15 \text { selected } \mathrm{D}_{5}=15 \mathrm{~cm} \\
\left(\mathrm{SN}_{1}{ }^{*}+\mathrm{SN}_{2}{ }^{*}\right)+(15 \times 0.13)=13.81+1.95=15.76 \geq 15.65\end{array}$} \\
\hline
\end{tabular}

Table 9. Flexible pavement layer thickness control for $20 \%$ BFS additive soil

\begin{tabular}{|c|c|c|c|c|c|c|c|c|c|c|c|}
\hline $\begin{array}{c}D_{1} \\
(\mathbf{c m})\end{array}$ & a1 & $\begin{array}{c}\mathrm{D}_{2} \\
(\mathbf{c m})\end{array}$ & $\mathbf{a}_{2}$ & $\begin{array}{c}\mathrm{D}_{3} \\
(\mathrm{~cm})\end{array}$ & $\mathbf{a} 3$ & $\begin{array}{c}\mathrm{D}_{4} \\
(\mathrm{~cm})\end{array}$ & $\mathbf{A}_{4}$ & $\begin{array}{c}D_{5} \\
(\mathbf{c m})\end{array}$ & A5 & $\begin{aligned} & \mathbf{S N}^{*} \\
= & \mathbf{a}_{\mathbf{i}} \times \mathbf{D}_{\mathbf{i}}\end{aligned}$ & Definitions \\
\hline 5 & 0.42 & 10 & 0.40 & 11 & 0.36 & - & - & - & - & $\begin{array}{c}\mathrm{SN}_{1}{ }^{*} \\
=10.06\end{array}$ & $\begin{array}{l}\text { For plentmix } \\
\text { crushed stone } \\
\text { base } \mathrm{SN}_{1}^{*}>\mathrm{SN}_{1} \\
(10.06>9.98)\end{array}$ \\
\hline \multicolumn{12}{|c|}{$\begin{array}{c}\mathrm{D}_{4}{ }^{*}=\left(\mathrm{SN}_{2}-\mathrm{SN}_{1}{ }^{*}\right) / \mathrm{a}_{4}=(13.51-10.06) / 0.15=23 \mathrm{~cm}, \text { Selected } \mathrm{D}_{4}=25 \mathrm{~cm} \\
\mathrm{SN}_{2}{ }^{*}=25 \times 0.15=3.75 \\
\mathrm{SN}_{1}{ }^{*}+\mathrm{SN}_{2}{ }^{*}=10.06+3.75=13.81 \geq 13.51\left(\mathrm{SN}_{2}\right)\end{array}$} \\
\hline \multicolumn{12}{|c|}{$\begin{array}{l}20 \% \text { BFS added soil for clay soil; } \mathrm{D}_{5} * \geq\left(\mathrm{SN}_{3}-\left(\mathrm{SN}_{1} *+\mathrm{SN}_{2} *\right)\right) / \mathrm{a}_{5} \\
\mathrm{D}_{5} * \geq 0, \mathrm{D}_{5}=0 \text { (subbase will not be made) } \\
\left(\mathrm{SN}_{1}{ }^{*}+\mathrm{SN}_{2}{ }^{*}\right)+(0 \times 0.13)=13.81+0=13.81 \geq 7.90\left(\mathrm{SN}_{3}\right)\end{array}$} \\
\hline
\end{tabular}




\subsection{Economic Analysis for Pure and $20 \%$ BFS Added Clay Soils}

In the study, the impact of BFS-improved clay soil on highway flexible pavement costs was evaluated based on the data of the General Directorate of Highways (GDH).

In unit price charts published by GDH, unit weight (ton) and unit volume $\left(\mathrm{m}^{3}\right)$ costs for subbase and base layers; Unit area $\left(\mathrm{m}^{2}\right)$ costs have been published for the bituminous base course, binder and wear layers. In the study, the 2019 GDH unit price item number was used for the economic analysis of highway pavements. In this context, the unit costs to be used within the scope of analysis for pure clay soil are given in Table 10 [27].

Table 10. Unit costs for pure clay soil according to layer types

\begin{tabular}{|l|l|c|c|}
\hline \multicolumn{1}{|c|}{ Item Number } & \multicolumn{1}{|c|}{ Definition and Unit } & $\begin{array}{c}\text { Unit Price } \\
\text { (TL) }\end{array}$ & $\begin{array}{c}\text { Cost of } \mathbf{~}^{2} / \mathbf{c m} \\
\text { (TL) }\end{array}$ \\
\hline GDH/6405/S-M & $\begin{array}{l}\text { Making } 1 \mathrm{~m}^{2} \text { asphalt concrete wear layer in } 5 \mathrm{~cm} \\
\text { compacted thickness, }\left(\mathrm{m}^{2}\right)\end{array}$ & 13.06 & 2.61 \\
\hline GDH/6320 & $\begin{array}{l}\text { Making asphalt concrete binder layer (with crushed } \\
\text { and screened quarry stone), (ton) Note: Coating } \\
\text { density } 2.40 \mathrm{~g} / \mathrm{cm}^{3}\end{array}$ & 83.78 & 2.02 \\
\hline GDH/6211-A & $\begin{array}{l}\text { Making } 1 \mathrm{~m}^{2} \text { asphalt concrete Bituminous base course } \\
\text { layer in } 11 \mathrm{~cm}^{2} \text { compacted thickness, }\left(\mathrm{m}^{2}\right)\end{array}$ & 20.11 & 1.83 \\
\hline GDH/6100/3 & $\begin{array}{l}\text { Making plant mix base }(\text { with broken and sieved quarry } \\
\text { stone), (ton) Note: Coating density } 2.40 \mathrm{~g} / \mathrm{cm}^{3}\end{array}$ & 40.49 & 0.97 \\
\hline GDH/6000 & $\begin{array}{l}\text { Making the subbase with crushed and screened } \\
\text { material from quarry stone, }\left(\mathrm{m}^{3}\right)\end{array}$ & 41.68 & 0.42 \\
\hline
\end{tabular}

In the calculation of the unit cost according to the layer types for the pure clay soil, the crushed stone subbase layer is $15 \mathrm{~cm}$, the plant mix base layer is $25 \mathrm{~cm}$, the bituminous base course layer is $11 \mathrm{~cm}$, the binder layer (asphalt concrete) is $10 \mathrm{~cm}$ and the wear layer (asphalt concrete) is $5 \mathrm{~cm}$ as shown in Table 6.

In the cost calculation of flexible road pavement, the cost of each layer was calculated by dividing the unit prices given in Table 10 by the thickness of the layer in terms of $" \mathrm{~m}^{2} / \mathrm{cm} "$, and the total and pavement unit cost has been determined. According to these calculations, the unit cost of the flexible road pavement thickness in $\mathrm{m}^{2} / \mathrm{cm}$ was obtained as $7.85 \mathrm{TL}$.

Similarly, in calculating the unit cost according to the layer types for clay soil with $20 \%$ BFS additive, the plant mix base layer was calculated as $25 \mathrm{~cm}$, bituminous base course layer $11 \mathrm{~cm}$, binder layer $10 \mathrm{~cm}$ and wearing layer (asphalt concrete) as $5 \mathrm{~cm}$ as also shown in Table 8 .

Table 11 shows the unit costs to be used within the scope of the analysis of $20 \%$ BFS added clay soil [27]. 
Table 11. Unit costs by layer types for $20 \%$ BFS added clay soil

\begin{tabular}{|c|l|c|c|}
\hline Item Number & \multicolumn{1}{|c|}{ Definition and Unit } & $\begin{array}{c}\text { Unit Price } \\
\text { (TL) }\end{array}$ & $\begin{array}{c}\text { Cost of } \\
\mathbf{m}^{2} / \mathbf{c m} \text { (TL) }\end{array}$ \\
\hline GDH/6405/S-M & $\begin{array}{l}\text { Making 1 } \mathrm{m}^{2} \text { asphalt concrete wear layer in } 5 \mathrm{~cm} \\
\text { compacted thickness, }\left(\mathrm{m}^{2}\right)\end{array}$ & 13.06 & 2.61 \\
\hline GDH/6320 & $\begin{array}{l}\text { Making asphalt concrete binder layer (with crushed } \\
\text { and screened quarry stone), (ton) Note: Coating } \\
\text { density } 2.40 \mathrm{~g} / \mathrm{cm}^{3}\end{array}$ & 83.78 & 2.02 \\
\hline GDH/6211-A & $\begin{array}{l}\text { Making } 1 \mathrm{~m}^{2} \text { asphalt concrete Bituminous base course } \\
\text { layer in } 11 \mathrm{~cm}^{2} \text { compacted thickness, }\left(\mathrm{m}^{2}\right)\end{array}$ & 20.11 & 1.83 \\
\hline GDH/6100/3 & $\begin{array}{l}\text { Making plant mix base (with broken and sieved quarry } \\
\text { stone), (ton) Note: Coating density } 2.40 \mathrm{~g} / \mathrm{cm}^{3}\end{array}$ & 40.49 & 0.97 \\
\hline
\end{tabular}

According to these calculations, the unit cost of the flexible road pavement thickness in $\mathrm{m}^{2} / \mathrm{cm}$ for $20 \%$ BFS added clay soil was obtained as 7.43 TL.

According to these calculations, 20\% BFS added clay soil reduces the unit cost by approximately $5.65 \%$ compared to pure clay soil in determining layer thicknesses. If the road soil is improved with $20 \%$ BFS on a divided road of $1000 \mathrm{~m}$ in length and $20 \mathrm{~m}$ in width, $8,400.00$ TL will be saved. Within the scope of similar studies conducted with waste material in the literature; In determining the thickness of the flexible road pavement layer, if the soil with $10 \%$ fly ash (FA) added clay soil and $10 \%$ FA on the $1000 \mathrm{~m}$ in length and $20 \mathrm{~m}$ in width divided road, the road soil is improved, 81,840.00 TL will be saved [28].

\section{CONCLUSIONS}

In this study, the effects of a clay subgrade soil, whose strength is increased by adding BFS, to highway flexible road pavement layer thicknesses and costs were obtained;

$\checkmark$ Due to the increase in the amount of BFS in the content of the clay soil, the optimum moisture content of the mixes increased and the maximum dry density values decreased. This is thought to be due to the high water absorption potential of the BFS and its fine grain structure.

$\checkmark$ According to the results of the unconfined compression test, the unconfined compression strength of the pure soil increased with the addition of BFS and the highest strength was obtained from mixtures containing $20 \%$ BFS. This result shows that BFS has a healing effect on the shear strength and cohesion ability of the clay soil.

$\checkmark$ According to CBR test results, 7 days of $20 \%$ BFS additives increased the CBR value of 7 days of pure clay soil approximately by 8.71 times. This significant increase shows that BFS has a very positive effect on the permanent deformation resistance of the clay soil.

$\checkmark$ According to layer thicknesses calculated for pure and additive soils, layer thickness for clayey soils containing $20 \%$ BFS showed a great decrease by $29.41 \%$ compared to pure soil. 
$\checkmark$ According to the cost calculation results, the cost of the pavement for clayey soils containing $20 \%$ BFS decreased by approximately $5.65 \%$ compared to the pure clay soil. due to the decrease in layer thicknesses.

$\checkmark$ Considering the unit costs for highway pavement layers, when the subgrade of a divided road of $1000 \mathrm{~m}$ in length and $20 \mathrm{~m}$ in width is improved with $20 \% \mathrm{BFS}, 8,400.00 \mathrm{TL}$ saving will be achieved in the cost of flexible road pavement compared to pure soil.

As a result, it was found that with the addition of BFS to a clayey subgrade, the strength of the subgrade increased significantly, and the flexible road pavement layer thicknesses and construction costs were reduced significantly. For this reason, it is thought that if the subgrades are improved with BFS, it will be very beneficial in terms of decreasing the road pavement cost and any possible damages to the environment. Additionally, operations such as storage and transportation of artificial pozzolanic materials such as BFS formed as a result of industrial activities lead to the occupation of fertile agricultural lands and serious damage to the environment. In this context, the use of waste materials such as BFS as road infrastructure filling material to form soil improvement; is of great importance in reducing environmental pollution, decreasing high costs due to stabilization of soils with poor bearing capacity and reusing waste materials [29].

\section{Acknowledgments}

This study has been supported by Inonu University Scientific Research Projects (SRP) Coordination Unit, project number FDK-2018-957.

\section{REFERENCES}

[1] Kozak, M. (2010). Investigation of the usage areas of textile wastes as building materials. Electronic Journal of Building Technologies, 6(1): 62-70.

[2] Aruntaş, H.Y. (2006). Potential use of fly ash in the construction industry. Journal of Gazi University Faculty of Engineering and Architecture, 21(1): 193-203.

[3] Tunç, A. (2002). Geotechnics and applications in road engineering. Atlas Publishing, Istanbul.

[4] Çakılcığlu, İ. (2007). Stabilization of high plasticity clays. Master Thesis, Sakarya University Institute of Science, Sakarya.

[5] Hausman, M.R. (1990). Engineering principles of ground modification. International Edition, 321-335.

[6] Kılıç, G. (2008). Ground stabilization with cement. Master Thesis, Yıldız Technical University Institute of Science, Istanbul.

[7] Emery, J.J, Kim, C.S, and Cotsworth, R.P. (1976). Base stabilization using pelletized blast furnace slag, 4(1):94-100.

[8] Öner, A, and Yıldırım, T. (2005). Effect of crushed stone sand content on concrete properties in concretes with and without ground blast furnace slag. Earthquake Symposium, Kocaeli.

[9] Tokyay, M. and Erdoğdu, K. (2002). Slags and slag cements. Cement Manufacturers Association of Turkey, Ankara.

[10] ACI 233.R-95, (2005). Ground granulated blast-furnace slag as a cementitious constituent in concrete. Reported by Ac1 Committee 233, American Concrete Institute, Detroit, Michigan. 
[11] Bilgen, G., Kavak, A., Yıldırım, S.T. and Çapar, Ö.F. (2010). The place and importance of blast furnace slag in the construction industry. Proceedings of the 2nd National Solid Waste Management Congress, Volume 1: 506513, Mersin.

[12] Bilgen, G. (2007). Ground stabilization with blast furnace slag. Master Thesis, Institute of Science, Kocaeli.

[13] Sivrikaya, O., Yavascan, S. and Cecen, E. (2014). Effects of ground granulated blast-furnace slag on the index and compaction parameters of clayey soils. Acta Geotechnica, 19-27.

[14] Bilgen, G., Kavak, A. and Çapar, Ö.F. (2012). The use of steel shop slag as an additive to a low-plasticity clay and its interaction with lime. Karaelmas Science and Engineering Journal, 2(2):30-38.

[15] Cokca, E., Yazici, V. and Ozaydin, V. (2009). Stabilization of expansive clays using granulated blast furnace slag (GBFS) and GBFS-cement. Geotechnical and Geological Engineering, 27: 489-499.

[16] Bilici, H., Okur, D.V., Türköz, M. and Savaş H. (2020). Fly Ash and Blast Furnace Slag on the Strength of Clay Soil Impact and Comparative Analysis of Contributions. BEU Journal of Science, 9 (2), 910-919.

[17] Geçkil, T., Sarıcı T. and Yıldıran E.S. (2019). Improving the Strength of a Clay Soil with Lime Additive. Çukurova University Journal of the Faculty of Engineering and Architecture, 34(4), pp. 171-179.

[18] Geçkil, T., Tanyıldızı, M.M. and Yıldıran E.S. (2020). Effects of a Clay Soil Stabilized by Blast Furnace Slag on Road Flexible Pavement Layer Thickness and Cost. Firat University Journal of Engineering Sciences, 32(2), 509-520.

[19] HTS (2013), Highways Technical Specifications Project Guide, Technical Research Department, Ankara.

[20] Arulrajah, A., Mohammadinia, A., Horpibulsuk, S. and Samingthong, W. (2016). Influence of class f fly ash and curing temperature on strength development of fly ash recycled concrete aggregate blends. Construction and Building Materials, 127:743-750.

[21] Gençdal, H., Berilgen, S. and Kılıç, H. (2020). Investigation of volume change behavior on compacted high plasticity clay ground for different initial conditions. Gazi University Journal of Engineering and Architecture Faculty. 35(3): 1421-1436.

[22] Öztürk, Y.Z., Ünsal, N and Akbaş, S.O (2015). Assessment of The Swellıng and Lıme Stabılızatıon Potentıal of Gölbaşı (Ankara) Resıdentıal Area Clays. Journal of the Faculty of Engineering and Architecture of Gazi University, 30(2): 309-318

[23] Gökalp, İ., Uz, V.E., Saltan, M. and Tutumluer, E. (2018). Technical and environmental evaluation of metallurgical slags as aggregate for sustainable pavement layer applications. Transportation Geotechnics, 14: 6169.

[24] American Association of State Highway and Transportation Officials, AASHTO Guide for Design of Pavement Structures. Washington, D.C.:1993.

[25] Highways Flexible Pavement Project Design Guide (2008), Technical Research Department, Ankara.

[26] Kök, B.V., Yılmaz, M. and Geçkil A. (2012). The effect of cement stabilized soil on flexible pavement cost. Pamukkale University Journal of Engineering Sciences, Volume 18, Number 3, Pages 165-172.

[27] http://www.birimfiyat.net, 2019.

[28] Geçkil, T., Tanyıldızı, M.M. and Yıldıran E.S. (2019). The Effects of a clay floor increased with fly ash on road pavement. I. International Scıence and Innovation Congress, 407-413.

[29] Uysal, F.F. and Selin Bahar, S. (2018). Slag Types and Ut1lization Areas. Trakya University Journal of Engineering Sciences, 19(1): 37-52. 